\title{
Towards a revision of Pseudobombax Dugand (Malvaceae- Bombacoideae): typification of names published by E. Hassler and R. Chodat in the related genus Bombax L.
}

\author{
Jefferson G. de Carvalho-Sobrinho, Lorenzo Ramella, Luciano P. de Queiroz \& Laurence J. Dorr
}

\begin{abstract}
CARVALHO-SOBRINHO, J. G. de, L. RAMELLA, L. P. de QUEIROZ \& L. J. DORR (2014). Towards a revision of Pseudobombax Dugand (Malvaceae-Bombacoideae): typification of names published by E. Hassler and R. Chodat in the related genus Bombax L. Candollea 69: 93-99. In English, English abstract.

To facilitate an ongoing taxonomic revision of Pseudobombax Dugand as part of studies on the systematics of Neotropical Bombacoideae (Malvaceae), we clarify the typification of 16 names in Bombacoideae that were published by Emil Hassler and Robert Chodat based mostly on specimens collected by Hassler in Paraguay and collected by Robert Fries and Gustaf Malme in Argentina and Brazil. We designate 4 lectotypes for the following names: Bombax elegans R. E. Fr., Bombax longiflorum var. emarginatum Hassl., Bombax marginatum subsp. meridionale Hassl., Bombax marginatum var. praecox Hassl. An epitype is designated for Bombax elegans R. E. Fr. In addition, we narrow down André Robyns' lectotypification of Bombax marginatum f. arboreum Chodat to a single specimen.
\end{abstract}

\section{Key-words}

MALVACEAE - Bombacoideae - Bombax - Pseudobombax Paraguay - Argentina - Brazil - Typification - Lectotype Two-step typification

\footnotetext{
Addresses of the authors: JGCS, LPQ: Programa de Pós-Graduação em Botânica, Universidade Estadual de Feira de Santana, Av. Universitária s/n, Novo Horizonte, 44036-900, Feira de Santana, Bahia, Brazil. E-mail: jef.sobrinho@gmail.com

LR: Conservatoire et Jardin botaniques de la Ville de Genève, case postale 60, 1292 Chambésy, Switzerland.

LJD: Department of Botany, Smithsonian Institution, Washington, D.C. 20013-7012, U.S.A.
} 


\section{Introduction}

Dugand (1943) created the genus Pseudobombax (Bombacoideae, Malvaceae) to accommodate several species from Central America that did not fit his concept of Bombax L. He considered Bombax to be a monospecific genus restricted to Central and South America and although he selected B. ceiba L. as type, it is clear from his description and the material that he cited that his concept of this species corresponds to what is now considered to be Pachira fendleri Seem. Subsequently, RoBYNs (1961) argued that B. ceiba could only be typified by an Asian element in its protologue and, ever since Robyn's choice of type was conserved (ICBN-Berlin, GREUTER \& al., 1988), Bombax has been considered to be a genus restricted to the Paleotropical region.

When Dugand (1943) described Pseudobombax, he transferred three species originally described in Bombax to his new genus: P. septenatum (Jacq.) Dugand (the type species), P. ellipticum (Kunth) Dugand, and P. palmeri (S. Watson) Dugand. Dugand (1943) also speculated that additional species of Bombacoideae probably would be transferred to Pseudobombax after a taxonomic revision of the group. RoBYNS (1963), in the last major comprehensive revision of Bombax s.l., expanded Pseudobombax by describing six new species and proposing 10 new combinations of which 9 were based on species described earlier in a more broadly defined Bombax.

Pseudobombax now is the second largest genus of the Bombacoideae (AlVERSON \& al., 1999; BAUM \& al., 1998, 2004; BAYER \& al., 1999; RoBYNs, 1963). It encompasses ca. 25 species inhabiting vegetation types predominantly associated with seasonal climate in the Neotropical region (CARVALHOSOBRINHO \& QueIroz, 2010, 2011; FERnANDEZ-Alonso, 2001). Species of Pseudobombax are mostly trees with unarmed trunks; the bark is usually marked with vertical, greenish stripes; the leaves are digitately compound and pulvinate and leaflets are not articulated with the petiole; the flowers are showy, reaching ca. $25 \mathrm{~cm}$ in length; the receptacle has conspicuous glands; the calyx is fleshy, accrescent in fruit, and marcescent; the filaments are numerous and partially connate in a tube; the anthers are monothecate and hippocrepiform; the capsules are woody and have abundant kapok; and the seeds are relatively small and numerous (CARVALHO-SOBRINHO \& QueIroz, 2010; CARVALHO-SOBrinho \& al., 2013a; RoByns, 1963). The distally dilated or expanded petiole with leaflets that lack an abcission zone where they join the petiole are probable synapomorphies for the genus (CARVALHO-SOBRINHO \& QueIROZ, 2011).

Collections of Pseudobombax often do not fit on a single herbarium sheet and require multiple sheets to be mounted because they have large leaves and flowers. In addition, their capsules are frequently bulky and can be stored separate from herbarium sheets in cross-referenced carpological collections.
However, well-curated carpological collections of Bombacoideae are scarce and frequently incomplete. The phenological phase of every sheet and separate element, including those comprising type specimens, is seldom clearly specified in the botanical literature (CARVALHO-SOBRINHO, pers. obs.). In addition, collections of Pseudobombax and other Bombacoideae from seasonally dry forest and savanna habitats are typically incomplete because species are commonly leafless during the flowering period; specimens often consist of leaves only or flowers only. Incomplete exsiccatae and incomplete carpological collections both commonly raise doubts regarding species circumscriptions (CARVALHOSobrinho \& QueIroz, 2010). Complicating matters, collectors who attempt to make complete exsiccatae of species that flower when they are leafless often create mixed collections of Neotropical Bombacoideae. There are even type specimens based on mixtures of elements from different families, which requires lectotypification in order to properly circumscribe names (CARVALHO-SOBRINHO \& al., 2013a; CARVALHOSOBRINHO \& al., 2013b).

The issues mentioned above depict idiosyncrasies of Bombacoideae taxonomy that represent a major challenge: matching separately-collected leaves, flowers, and fruits in order to better circumscribe a taxon (CARVALHO-SOBRINHO \& QUEIROZ, 2008, 2010; CARvalho-Sobrinho \& al., 2012; CARVAlhoSoBrinHo \& al., 2014). These issues also highlight the importance of clarifying and typifying names in this group.

During a taxonomic revision of Pseudobombax (CARVALHOSOBRINHO \& al., in prep.), we realized that several names of infraspecific taxa in the genus Bombax published by CHODAT (1904) and HASSLER $(1910,1913)$ that were based mostly on specimens collected by Hassler in Paraguay and that are associated with Pseudobombax require clarification and in some instances lectotypification.

Altogether we discuss the typification and status of 16 names in Bombacoideae that were described based on material from Argentina, Brazil, and especially from Paraguay, and designate 4 lectotypes and 1 epitype for 4 of these 16 names. Clarification of the types of these names will assist in the taxonomic revision of Pseudobombax and contribute to a monograph of Bombacoideae for the Flora of Paraguay and adjacent countries.

\section{Material and methods}

We carefully examined the taxonomic literature on Bombacoideae in order to check typifications and synonymies of taxa based on collections from Paraguay. In addition to the work of CHODAT (1904) and HASSLER $(1910,1913)$, we evaluated the revision by RoBYNS (1963) of Bombax L. s.l. and subsequent nomenclatural publications related to Pseudobombax from Bolivia (CARVALHO-SOBRINHO \& al., 2013a), Brazil 
(CARvalho-Sobrinho \& QueIroz, 2010; CARvalho-Sobrinho \& al., 2013b), and Colombia (FERnANDEZ-Alonso, 1999, 2001). The controversial paper by RAVENNA (2005) also was reviewed.

Collections of Bombacoideae deposited in the following herbaria were examined: ALCB, BHCB, CEN, CEPEC, CVRD, F, G, HAMAB, HRB, HUEFS, IAC, IBGE, INPA, IPA, K, M, MBM, MBML, MO, NY, P, PEUFR, R, RB, S, SJRP, SP, SPF, SJRP, UB, UEC, UFP, US, VIC, and WIS. Special attention was given to $\mathrm{G}$ where original collections made in Paraguay by Hassler are deposited. Hassler's collections of Bombacoideae are mostly comprised of leaves and flowers mounted in multiple sheets and incomplete duplicates were occasionally found in other herbaria that were visited. Collections of BM, LIL, MICH, and MPU were accessed through JSTOR (2014). Phenological phases of each sheet comprising type specimens were checked and are indicated below (as "If" for the presence of leaves, "fl" for flowers, and "fr" for fruits) in order to facilitate a more precise taxonomy of the group.

For a given infraspecific name it was sometimes necessary to clarify which of several duplicates of a specimen was the holotype. We did this by examining pertinent specimens for the presence of the author's handwriting and any other written indication that the author had selected a specimen as type (see also ICBN-Melbourne, Art. 9.1). Lectotypes were selected from the original material that best matched critical morphological characters mentioned in protologues.

\section{Lectotypifications and clarifications of type status}

1. Bombax cyathophorum var. latifoliolatum Hassl. in Repert. Spec. Nov. Regni Veg. 12: 255. 1913.

Holotypus: ParaguaY. Amambay: "In altaplanitie Sierra de Amambay", V.1912-1913, Hassler, E. 11240 (G [G00094602]! [lf, fl]). Isotypi : (G [G00094600]! [lf, fl], G [G00094601]! [lf, fl], G [G00094603]! [lf, fl], K! [lf], $\mathrm{K}$ ! [lf, fl], P [P06622842]! [lf, fl]).

2. Bombax cyathophorum var. longipes Hassl. in Repert. Spec. Nov. Regni Veg. 12: 255. 1913.

Holotypus: Paraguay. Amambay: "In altaplanitie Sierra de Amambay", V.1912-1913, Hassler, E. 11240a (G [G00094608]! [lf, fl]). Isotypi : (G [G00094607]! [lf, fl], $\mathrm{P}[\mathrm{P} 06622841]$ ! [lf, fl]).

3. Bombax longiflorum f. elegans (R. E. Fr.) Hassl. in Repert. Spec. Nov. Regni Veg. 8: 68. 1910.

$\equiv$ Bombax elegans R. E. Fr. in Kongl. Svenska Vetensk. Acad. Handl. 42(12): 27. 1908.
Lectotypus (in hoc loco designatus): BRAzIL. State of Mato Grosso : "Brasiliae civit. Matto Grosso: Cuyabá. In cerrado", 4.VII.1903, Malme, G. O. A. s.n. (S [SR11279] [image]! [fl]).

Epitypus (in hoc loco designatus): BRAzIL. State of Mato Grosso: "Brasiliae civit. Matto Grosso: Cuyabá", 4.XII.1902, Malme, G. O. A. s.n. (S [S10-38650]! [lf]). Isoepitypus: (S [SR11280] [image]! [1f]).

Two specimens collected by Malme were used by Fries to describe and illustrate B. elegans (FRIES, 1908: 27-28, plate IV) and thus they are syntypes of this name. The collection dated 4.VII.1903 [SR11279] has several, separate floral buds and juvenile flowers, and the collections dated from 4.XII.1902 have mature, seven-foliolate leaves ([SR11280], [S10-38650]). RoBYNS (1963: 59) considered both vegetative and reproductive specimens as type material of B. elegans: "jul. 1903, Malme s.n. (f., fl.; holotypus B. elegans $S)$ ", but he failed to designate a lectotype for this name. We designate the flowering specimen as the lectotype for B. elegans based on both Fries' indication of new species status "Bombax elegans $R$. E. Fr. n. sp." as well as indication of the habitat ("In cerrados") on the specimen label that match Fries' protologue.

Since the present lectotype lacks leaves, which represent diagnostic characters for B. elegans (FRIES, 1908: 27-28), we designate the specimen [S10-38650] as an epitype to permit a precise application of the name in accordance with Art. 9.8 (ICBN-Melbourne).

The lectotype and epitype of $B$. elegans are also syntypes of $B$. longiflorum var. emarginatum.

4. Bombax longiflorum var. emarginatum Hassl. in Repert. Spec. Nov. Regni Veg. 8: 68. 1910.

Lectotypus (in hoc loco designatus): Paraguay. Amambay: "Sierra de Amambay in campis serrados Esperanza", XI.1907-1908, Hassler, E. \& T. Rojas 10848 (G [G0009 4606]! [1f, fr]).

Syntypi: BrazIL. State of Mato Grosso: "Brasiliae civit. Matto Grosso: Cuyabá”, 4.XII.1902, Malme, G. O. A. s.n. (S [SR11280] [image]! [1f], S [S10-38650]! [1f]); "Brasiliae civit. Matto Grosso: Cuyabá. In cerrado", 4.VII.1903, Malme, G. O. A. s.n. (S [SR11279] [image]! [fl]).

Under B. longiflorum var. emarginatum, HASSLER (1910: 68 ) accommodated $B$. longiflorum $\mathrm{f}$. multifoliolatum as a different taxon from B. longiflorum f. elegans (R. E. Fr.) Hassl. ( $\equiv$ B. elegans R. E. Fr.). However, Hassler did not designate a holotype for var. emarginatum. Types of the names of the two forms published by him (see under their names) are syntypes of this variety. We choose as lectotype of this variety the specimen that is also the holotype of B. longiflorum $\mathrm{f}$. multifoliolatum as it allows a clear application of the present 
name according to Hassler's concept. The syntype Malme s.n. [SR11279] is also the lectotype of B. elegans, and the syntype Malme s.n. [S10-38650] is also epitype of B. elegans.

5. Bombax longiflorum f. multifoliolatum Hassl. in Repert. Spec. Nov. Regni Veg. 8: 68. 1910.

Holotypus: ParaguaY. Amambay: "Sierra de Amambay in campis serrados Esperanza”, XI.1907-1908, Hassler, E. \& T. Rojas 10848 (G [G00094606]! [1f, fr]).

Hassler \& Rojas 10848 is also the lectotype of B. longiflorum var. emarginatum.

6. Bombax marginatum f. apaense Hassl. in Repert. Spec. Nov. Regni Veg. 8: 70. 1910.

Holotypus: Paraguay. Concepción: "In dumetis prope Rio Apa”, V.1885-1895, Hassler, E. 410 (G [G00307102]! [lf, fl]). Isotypi : (G [G00307100]! [fl], G [G00307101]! [fl], K! [fl], NY [NY00133529]! [fl], NY [NY00133530]! [fl], P [P06622878]! [fl], P [P06622882]! [fl]).

The specimen [G00307102] has not been annotated as form apaense by Hassler, but it is the only one with leaf and flowers and thus the only specimen matching the protologue. The specimen [G00307101] was annotated by Hassler but it does not include any leaf material.

The form apaense is included in B. marginatum var. arboreum (Chodat) Hassl. and Hassler 410 is also the lectotype of its basionym B. marginatum f. arboreum Chodat.

7. Bombax marginatum var. arboreum (Chodat) Hassl. in Repert. Spec. Nov. Regni Veg. 8: 70. 1910.

$\equiv$ Bombax marginatum f. arboreum Chodat in Bull. Herb. Boissier ser. 2, 5: 72. 1904.

Lectotypus (gathering designated by ROBYNS, 1963; specimen in hoc loco designatum): Paraguay. Concepción : "In dumetis prope Rio Apa", V.1885-1895, Hassler, E. 410 (G [G00307102]! [1f, fl]). Isolectotypi : (G [G00307100]! [fl], G [G00307101]! [fl], K! [fl], NY [NY00133529]! [fl], NY [NY00133530]! [fl], P [P06622878]! [fl], P [P0662 2882]! [fl]).

Syntypi : Paraguay. Cordillera: "In rupestribus Cordillera de Altos”, II.1898-1899, Hassler, E. 6031 (G [G00077086]! [lf, fl], G [G00094589]! [lf, fl], G [G00094590]! [lf, fl], G [G00094591]! [lf, fl]), LIL [LIL000882] [image]! [fl], MICH [MICH1210020] [image]! [lf, fl], MO [MO309212]! [lf, fl], P [P00634474]! [lf], P [P00634475]! [fl], P [P06622935]! [lf], P [P06622940]! [fl], S [S10-34541]! [lf, fl]).

RoByns (1963: 79) designated Hassler 410 as holotype of Pachira marginata f. arborea, and this designation is correctable to lectotype (ICBN-Melbourne, Art. 9.9).
The exact citation of $P$. marginata f. arborea in RoBYNS (1963: 77) is: "Pa. [Pachira] marginata f. arborea Chodat et Hassl., loc. cit. [Bull. Herb. Boiss. ser. 2, V], p. 72 (1905)”. In the original publication, CHODAT (1904: 72) mentions in this place: "Bombax marginatum K. Sch. [...] forma arborea". Furthermore P. marginata A. St.-Hil. \& al. is the basionym of B. marginatum (A. St.-Hil. \& al.) K. Schum. We consider then P. marginata f. arborea in RoBYNS $(1963: 77,79)$ therefore to be a lapsus calami. We believe that Robyns intended B. marginatum f. arboreum, as did CHODAT (1904: 72), since Robyns' concept of Pachira included only P. aquatica Aubl. and P. insignis (Sw.) Savigny (RoBYNs, 1963: 233).

Robyns annotated 2 duplicates of Hassler 410 in G ([G00 307101], [G00307102]) but he did not designate either one of them as the lectotype. In the sense of Art. 9.17 (ICBNMelbourne) we complete herein Robyns' typification by narrowing down his selection to the only duplicate with both leaves and flowers as lectotype.

Under B. marginatum var. arboreum, HASSLER (1910: 70) described B. marginatum f. apaense (holotype: Hassler 410) and B. marginatum f. rupestre (holotype: Hassler 6031).

8. Bombax marginatum f. argentinum (R. E. Fr.) Hassl. in Repert. Spec. Nov. Regni Veg. 8: 70. 1910.

$\equiv$ Bombax argentinum R. E. Fr. in Ark. Bot. 6(2): 3. 1906.

Holotypus: Argentina. Province of Jujuy: "Quinta pr. Laguna de la Brea in silva minus densa", 5.VI.1901, Fries, R. E. 126 (S [SR11277] [image]! [lf, fl]). Isotypi : (S [S06-7888] [image]! [fl], S [S09-1901] [image]! [fl], S [S09-4073] [image]! [fr]).

9. Bombax marginatum var. cuspidatum Hassl. in Repert. Spec. Nov. Regni Veg. 12: 256. 1913.

Holotypus: Paraguay. Amambay: "Cerrados region C. Margarita", II.s.a., Hassler, E. \& T. Rojas 11005 (G [G000 94596]! [lf, fl]).

10. Bombax marginatum f. fiebrigii Hassl. in Repert. Spec. Nov. Regni Veg. 8: 71. 1910.

Holotypus: Paraguay. Concepción: “Caballero-cue”, II.1908-1909, Fiebrig, K. 5244 (G [G00094587]! [lf, fl]). Isotypi : ( $\mathrm{G}$ [G00307098]! [1f, fl], K [K001050343]! [1f, fl], M [M0211667]! [lf, fl]).

The present holotype, Fiebrig 5244, is also the lectotype of $B$. marginatum subsp. meridionale and B. marginatum var. praecox. 
11. Bombax marginatum f. fruticosum Chodat in Bull. Herb. Boissier ser. 2, 5: 73. 1904.

Holotypus: Paraguay. Amambay: "In campis in regione cursus superioris fluminis Apa", XII.1901-1902, Hassler, E. 8237 (G [G00094612]! [lf, fl]). Isotypi : (G [G00094 610]! [lf, fl], G [G00094611]! [lf, fl], K! [lf, fl], LIL [LIL000883] [image]! [lf, fl], MO [MO309148]! [lf, fl], MPU [MPU016295] [image]! [1f, fl], P [P04694199]! [lf, fl], P [P04694200]! [lf], P [P04694201]! [1f], P [P04694 202]! [lf], P [P06622938]! [lf, fl], P [P06622939]! [lf, fl], RB [RB94114]! [lf], S [S10-34539]! [lf, fl], US [US00811 396]! [lf, fl]).

Part of the gathering Hassler 8237 was later (HASSLER, 1910: 69) used as type of B. marginatum var. intermedium (see below) as Hassler 8237 p.p. (i.e. pro parte).

12. Bombax marginatum var. intermedium Hassl. in Repert. Spec. Nov. Regni Veg. 8: 69. 1910.

Holotypus: Paraguay. Amambay: "In regione cursus superioris fluminis Apa", XII.1901-1902, Hassler, E. 8237 [a] (G [G00094599]! [lf, fl]).

The type of $B$. marginatum var. intermedium was indicated by Hassler in the original description as Hassler 8237 p.p. (i.e. pro parte). To make the distinction with the type of $B$. marginatum f. fruticosum based on part of the same gathering (see above) the letter [a] has been added to this particular specimen. Hassler did annotate it with his own handwriting: "Bombax marginatum K. Sch. subspec. meridionale Hassler var. intermedium Hassler".

13. Bombax marginatum subsp. meridionale Hassl. in Repert. Spec. Nov. Regni Veg. 8: 69. 1910.

Lectotypus (in hoc loco designatus): Paraguay. Concepción: “Caballero-cue”, II.1908-1909, Fiebrig, K. 5244 (G [G00094587]! [lf, fl]). Isolectotypi : (G [G00307098]! [lf, fl], K [K001050343]! [lf, fl], M [M0211667]! [lf, fl]).

HASSLER (1910: 69) described B. marginatum subsp. genuinum based on Hassler 8237 p.p. to accommodate the typical marginatum apart from $B$. marginatum subsp. meridionale. However, according to Art. 26.2 (ICBN-Melbourne), the name genuinum is a superfluous name for B. marginatum subsp. marginatum (Art. 52.1) that was automatically established (whether or not it appears in the publication in which taxa are created) when Hassler validly published the subspecies meridionale (Arts. 6.8, 26.3, and 32.3). The type of B. marginatum subsp. marginatum is a St.-Hilaire collection from Brazil.

Under B. marginatum subsp. meridionale, HASSLER (1910: 69-70) accommodated three new varieties: intermedium, arboreum, and praecox. However, he did not designate a holotype for subspecies meridionale. Types of the names published by him within meridionale (five forms and three varieties) are syntypes of this subspecies.

Based on Hassler's diagnoses, two clear-cut characters were used to distinguish his two new subspecies: the indumentum of the ovaries and the indumentum of fruits. No fruits were found in Hassler's collections for subspecies genuinum or meridionale. Nevertheless, the existence of tomentose ovaries can be seen in type specimens of the varieties. We choose the type of the form fiebrigii that allows a clear application of the name of this subspecies meridionale according to Hassler's concept.

The present lectotype, Fiebrig 5244, is also the lectotype of $B$. marginatum var. praecox and the holotype of $B$. marginatum f. fiebrigii.

14. Bombax marginatum var. praecox Hassl. in Repert. Spec. Nov. Regni Veg. 8: 70. 1910.

Lectotypus (in hoc loco designatus): Paraguay. Concepción: “Caballero-cue”, II.1908-1909, Fiebrig, K. 5244 (G [G00094587]! [lf, fl]). Isolectotypi : (G [G00307098]! [lf, fl], K [K001050343]! [lf, fl], M [M0211667]! [lf, fl]).

Under B. marginatum var. praecox, HASSLER (1910: 68) accommodated the new forms paraguayense, argentinum, and fiebrigii based on the presence of glabrous staminal tubes. However, he did not designate a holotype for this variety. Types of the names of the three forms are syntypes of the variety. We choose the type of the form fiebrigii that allows a clear application of the name of this variety according to Hassler's concept.

The present lectotype, Fiebrig 5244, is also the holotype of $B$. marginatum $\mathrm{f}$. fiebrigii and the lectotype of $B$. marginatum subsp. meridionale.

15. Bombax marginatum f. rupestre Hassl. in Repert. Spec. Nov. Regni Veg. 8: 70. 1910.

Holotypus: Paraguay. Cordillera: "In rupestribus Cordillera de Altos", II.1898-1899, Hassler, E. 6031 (G [G00094591]! [lf, fl]). Isotypi: (G [G00077086]! [lf, fl], G [G00094589]! [lf, fl], G [G00094590]! [lf, fl], LIL [LIL000882] [image]! [fl], MICH [MICH1210020] [image]! [lf, fl], MO [MO309212]! [lf, fl], P [P00634474]! [lf], P [P00634475]! [fl], P [P06622935]! [lf], P [P06622 940]! [fl], S [S10-34541]! [lf, fl]).

The present holotype, Hassler 6031, is also a syntype of B. marginatum f. arboreum. 
16. Bombax martianum subsp. guaraniticum Hassl. in Repert. Spec. Nov. Regni Veg. 12: 255. 1913.

Holotypus: ParaguaY. Amambay: "In altaplanitie Sierra de Amambay. Cerrados altos - Limeira", V[lf, fl]-X[fr]. 1912-1913, Hassler, E. \& T. Rojas 11216 (G [G0007 7083]! [lf, fl, fr]). Isotypi : (BM [BM000545864] [image]! [lf, fl], G [G00077084]! [lf, fl], G [G00094614]! [lf, fl], G [G00094615]! [lf, fl], K! [lf, fl], P [P06622881]! [lf, fl]).

The holotype and two isotypes ([G00094614], [G00094 615]) are dated 1912-1913. The specimen that we consider to be the holotype is found in Hassler's original herbarium and he wrote "subsp. guaraniticum Hassler" on this specimen. We consider the specimen [G00077084], which is dated 19071908 , to be an isotype despite the date conflict. Hassler wrote "ssp. guaraniticum K. Sch." on this latter specimen.

\section{Acknowledgements}

Thanks are due to the staff and curators of herbaria visited by JGCS, especially Nicolas Fumeaux (G), Martin Cheek, Lee Davies and Cátia Canteiro (K), Hans-Joachim Esser (M), Jacques Florence and Cláudia Gonçalves (P) and Mia Ehn (S) for making images of the type of $B$. argentinum available; to Aline C. Mota for help during the work in the European herbaria; and the Fundação de Amparo à Pesquisa do Estado da Bahia FAPESB (process APP0006/2011) and the Conselho Nacional de Desenvolvimento Científico e Tecnológico - $\mathrm{CNPq}$ (process 300811/2010-1) for financial support. This paper is part of the $\mathrm{PhD}$ thesis of JGCS prepared in the Programa de Pós-Graduação em Botânica (PPGBot - UEFS) and supported by a grant from the Coordenação de Aperfeiçoamento de Pessoal de Nível Superior-CAPES and a sandwich fellowship through the Reflora programme (CAPES process BEX 5415/13-6).

\section{References}

Alverson, W. S., B. A. Whitlock, R. Nyffeler, C. Bayer \& D. A. BAUM (1999). Phylogeny of the core Malvales: evidence from ndhf sequence data. Amer. J. Bot. 86: 1474-1486.

Baum, D. A., W. S. Alverson \& R. Nyffeler (1998). A durian by any other name: taxonomy and nomenclature of the core Malvales. Harvard Pap. Bot. 3: 315-330.

Baum, D. A., S. D. Smith, A. Yen, W. S. Alverson, R. Nyffeler, B. A. Whitlock \& R. L. Oldham (2004). Phylogenetic relationships of Malvatheca (Bombacoideae and Malvoideae; Malvaceae sensu lato) as inferred from plastid DNA sequences. Amer. J. Bot. 91 : 1863-1871.

Bayer, C., M. F. Fay, A. Y. De Bruijn, V. Savolainen, C. M. Morton, K. Kubitzki, W. S. Alverson \& M. W. Chase (1999). Support for an expanded family concept of Malvaceae within a recircumscribed order Malvales: a combined analysis of plastid atpB and rbcL DNA Sequences. Bot. J. Linn. Soc. 129: 267-303.

Carvalho-Sobrinho, J. G. de \& L. P. de Queiroz (2008). Ceiba rubriflora (Malvaceae: Bombacoideae), a new species from Bahia, Brazil. Kew Bull. 63: 649-653.

Carvalho-Sobrinho, J. G. de \& L. P. de QueIroz (2010). Three new species of Pseudobombax (Malvaceae, Bombacoideae) from Brazil. Novon 20: 13-20.

Carvalho-Sobrinho, J. G. de \& L. P. de Queiroz (2011). Morphological cladistic analysis of Pseudobombax Dugand (Malvaceae, Bombacoideae) and allied genera. Revista Brasil. Bot. 34: 197-209.

Carvalho-Sobrinho, J. G. de, M. C. Machado \& L. P. de Queiroz (2012). Spirotheca elegans (Malvaceae: Bombacoideae), a new species from Bahia, Brazil. Syst. Bot. 37: 978-982.

Carvalho-Sobrinho, J. G. de, L. P. de Queiroz \& L. J. Dorr (2013a). Does Pseudobombax have prickles? Assessing the enigmatic species Pseudobombax endecaphyllum (Malvaceae: Bombacoideae). Taxon 62: 814-818.

Carvalho-Sobrinho, J. G. de, L. P. de Queiroz \& W. S. Alverson (2013b). Reinterpretation of the nomenclatural type of Pseudobombax heteromorphum (Malvaceae, Bombacoideae) reveals an overlooked new species from Bolivia. PhytoKeys 21: 53-61.

Carvalho-Sobrinho, J. G. de, W. S. Alverson, A. C. Mota, M. C. MACHADO \& D. A. BAUM (2014). A new deciduous species of Pachira (Malvaceae: Bombacoideae) from a seasonally dry tropical forest in northeastern Brazil. Syst. Bot. 39: 260-267.

Chodat, R. (1904). Bombacaceae. In: Chodat, R. \& E. HAssler (ed.), Plantae Hasslerianae. Bull. Herb. Boissier ser. 2, 5: 72-73.

Dugand, A. (1943). Revalidación de Bombax ceiba L. como especie típica del género Bombax L. y descripción de Pseudobombax gen. nov. Caldasia 2: 47-68.

FernándeZ-Alonso, J. L. (1999). Sobre la identidad de Pseudobombax squamigerum y de Eriotheca gentryi (Bombacaceae). Anales Jard. Bot. Madrid 57: 162-164.

FERnÁNDEZ-Alonso, J. L. (2001). Bombacaceae neotropicae novae vel minus cognitae V. Novedades en Pseudobombax Dugand y sinopsis de las especies Colombianas. Revista Acad. Colomb. Ci. Exact. 25: 467-476.

FrIES, R. E. (1908). Studien über die amerikanische Columniferenflora; Fam. Bombaceae. Kongl. Svenska Vetensk. Acad. Handl. 42(12): 27-28.

Greuter, W., H. M. Burdet, W. G. Chaloner, V. Demoulin, R. Grolle, D. L. Hawksworth, D. H. Nicolson, P. C. Silva, F. A. Stafleu, E. G. Voss \& J. McNeill (ed.) (1988). International Code of Botanical Nomenclature (Berlin Code). Regnum Veg. 118.

HASSLER, E. (1910). Ex herbario Hassleriano: Novitates paraguarienses. V. Bombacaceae. Repert. Spec. Nov. Regni Veg. 8: 66-71.

HAssler, E. (1913). Ex herbario Hassleriano: Novitates paraguarienses. XVII. Bombacaceae II. Repert. Spec. Nov. Regni Veg. 12: 255-256.

JSTOR (2014). JSTOR Global Plants. [http://plants.jstor.org]. 
Ravenna, P. (2005). New species of South American Pseudobombax, noteworthy Ceiba species, and a new section with C. jasminodora as type (Bombacaceae). Onira 10: 27-34.

RoByns, A. (1961). Contribution à l'étude monographique du genre Bombax s.1. II. La typification de B. Ceiba L. Taxon 10: 156-160.

Robyns, A. (1963). Essai de monographie du genre Bombax s.1. (Bombacaceae). Bull. Jard. Bot. Etat Bruxelles 33: 1-315. 